\title{
Synthesis of a Phthaloylglycine-Derived Strigol Analogue and Its Germination Stimulatory Activity toward Seeds of the Parasitic Weeds Striga hermonthica and Orobanche crenata
}

\author{
Gérard H. L. Nefkens, J an Willem J . F. Thuring, Marco F. M. Beenakkers, and \\ Binne Zwanenburg*
}

NSR-Center for Molecular Structure, Design and Synthesis, Department of Organic Chemistry, University of Nijmegen, Toernooiveld, 6525 ED Nijmegen, The N etherlands

\begin{abstract}
The newly designed strigol analogue Nijmegen 1 (rac 7) was prepared in high overall yield starting from $\mathrm{N}$-phthal oylglycine. This relatively simple analogue exhibits high bioactivity in the stimulation of germination of seeds of the parasitic weeds Striga hermonthica and Orobanchecrenata. Nijmegen 1 was resolved in its enantiomers $\mathbf{7}$ and ent $\mathbf{7}$ by using the homochiral latent D-rings ent $\mathbf{1 1}$ and ent 12. The enantiomers $\mathbf{7}$ and ent $\mathbf{7}$ show significant differences in germination activity.
\end{abstract}

Keywords: Striga; Orobanche; germination; strigol analogue

\section{INTRODUCTION}

The devastating parasitic weeds Striga and Orobanche cause severe reductions in food crop yield of several graminaceous and leguminous crops in tropical and semitropical areas of the eastern hemisphere (Musselman, 1987; Parker and Riches, 1993). A strict requirement for the germination of the seeds of these parasitic weeds is exposure to a chemical substance that is usually present in the root exudate of a potential host plant (Press et al., 1990; Butler, 1995). An attractive control strategy for the eradication of infested fields is the concept of suicidal germination, i.e introduction of a germination stimulating agent into the soil prior to sowing to induce germination of the parasitic seeds in the absence of a host plant (Eplee, 1975). The first known naturally occurring germination stimulant, (+)strigol (1), was isolated from the root exudate of the false host cotton (Gossypium hirsutum L.) (Cook et al., 1966, 1972). Recently, (+)-strigol (1) was also identified in the root exudates of the Striga host plants maize (Zea mays L.) and proso millet (Panicum miliaceum L.) (Siame et al., 1993). In addition, some structurally closely related "strigolactones" (Butler, 1995) have been identified in the root exudates of other Striga hosts, viz. sorgolactone 2 (Hauck et al., 1992) and al ectrol 3 (Müller et al., 1992).

However, strigolactones 1-3 (Figure 1) are not suitable for weed control purposes, because their structures are too complicated to allow synthesis in an economically feasible manner. Ther efore, several studies aimed at synthetic analogues with a relatively simple structure but with high germination stimulatory activity $(\mathrm{J}$ ohnson et al., 1976, 1981; Vail et al., 1990; Bergmann et al., 1993; Mangnus et al., 1992a; Zwanenburg et al., 1994). These studies mainly focused on the ABC-part of the strigolactones. In this part of the molecule a considerable structural variation is allowed to retain high biological activity. On the basis of these observations, a tentative molecular mechanism (Scheme 1), which accounts for the onset of the biochemical cascade leading to germination, has been proposed (Mangnus and Zwanenburg, 1992a). According to this mechanism the bioactiphore resides in the vinyl ether part of the D-ring.

\footnotetext{
*Fax +31.24.3652929; e-mail zwanenb@sci.kun.nl
}

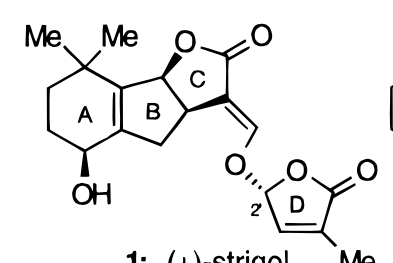

1: (+)-strigol
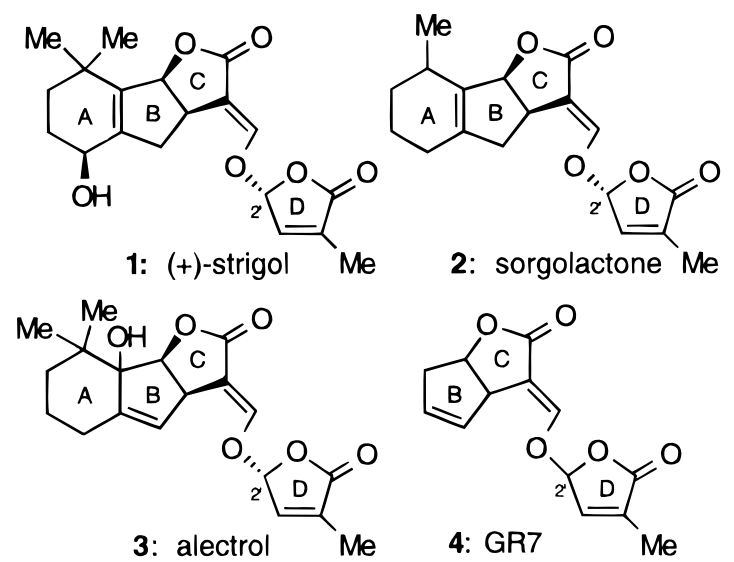

2: sorgolactone $\mathrm{Me}$
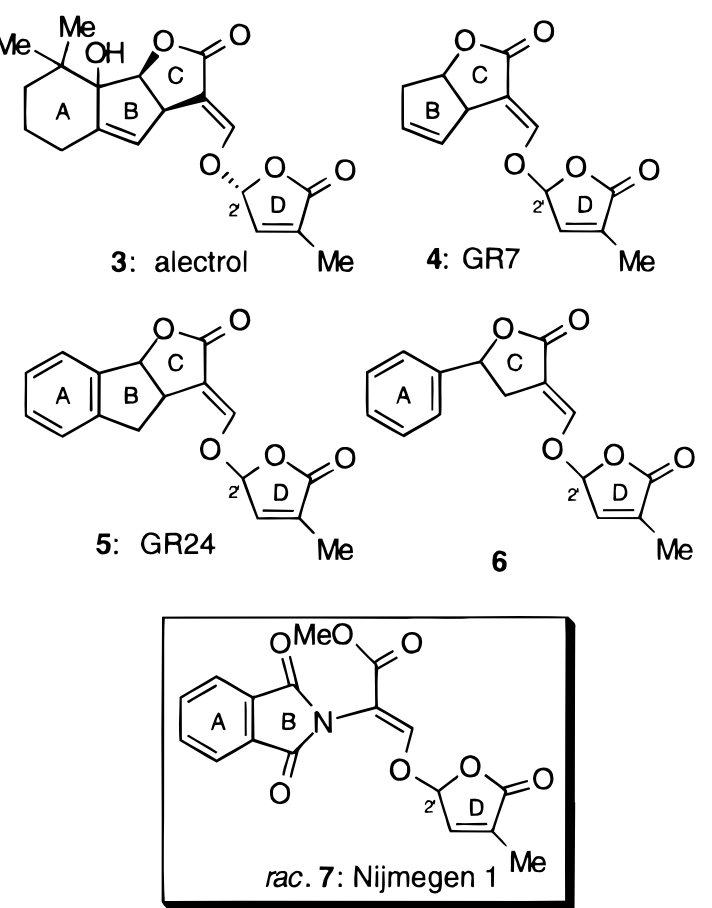

Figure 1. Strigolactones $\mathbf{1 - 3}$ and some active analogues.

I mportant examples of highly potent synthetic analogues include 4 (GR7) and 5 (GR24) (J ohnson et al., 1981; Mangnus and Zwanenburg, 1992b; Mangnus ef al., 1992b). The latter, having an aromatic A-ring, is especially highly relevant, as its stimulatory activity is comparable to that of strigol (Bergmann et al., 1993) and its preparation is much easier than that of strigol (Mangnus et al., 1992b). An even less complicated analogue is compound 6, derived from $\gamma$-phenyl- $\gamma$ butyrolactone. This analogue, which lacks the B-ring, is almost as active as GR24 (Mangnus et al., 1992a). A 
Scheme 1. Proposed Molecular Mechanism Involved in Germination

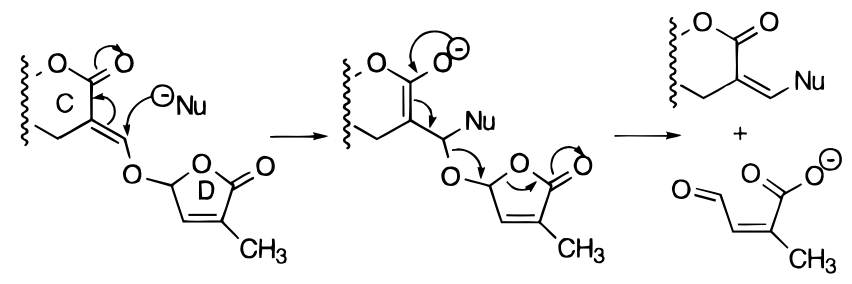

problem associated with the analogues 4-6 is the presence of two stereogenic centers in these molecules with the consequence that during their syntheses mixtures of diastereomers are obtained, which can be separated only by tedious chromatography. The present paper describes the synthesis of phthaloylglycinederived strigol analogue rac $\mathbf{7}$, which we named Nijmegen 1 , and the evaluation of the germination stimulatory activity toward seeds of Striga and Orobanchespp. This new germination stimulant contains only one chiral center, viz. in the D-ring. This compound was designed in such a manner that it contains the essential structural features for bioactivity (vide supra); that is, the essence of the molecular mechanism is not affected. Its planar phthalimido moiety is entirely divergent from that of the ABC-part of the strigolactones 1-3 and the GR analogues $\mathbf{4}$ and $\mathbf{5}$.

\section{MATERIALS AND METHODS}

Nomenclature. We have used the AUTONOM 1.0 program, provided by the Beilstein I nstitute and Springer-Verlag, Weinheim, Germany.

Syntheses. General Remarks. ${ }^{1} \mathrm{H}-\mathrm{NMR}(100 \mathrm{MHz})$ spectra were recorded on a Bruker AC 100 spectrometer (Me $\mathrm{M}_{4} \mathrm{Si}$ as internal standard), and $400 \mathrm{MHz}{ }^{1} \mathrm{H}-\mathrm{NMR}$ spectra were recorded on a Bruker AM-400 spectrometer (MesSi as internal standard), both from Bruker (Wissembourg, France). All coupling constants are given as ${ }^{3} \mathrm{~J}$ in hertz, unless indicated otherwise. For mass spectra a double-focusing VG7070E mass spectrometer from VG Analytical (Manchester, U.K.) was used. GLC was conducted with a Hewlett-Packard HP 5890 gas chromatograph, from Hewlett-Packard Nederland (Amstel veen, The Netherlands), using a capillary cross-linked methyl silicone gum column of $25 \mathrm{~m}$ length and $0.32 \mathrm{~mm}$ i.d., with $0.17 \mu \mathrm{m}$ film thickness and nitrogen $(2 \mathrm{~mL} / \mathrm{min}, 0.5 \mathrm{~atm})$ as the carrier gas. Melting points were measured with a Reichert Thermopan (Austria) microscope and are uncorrected. EIemental analyses were performed at the Department of Microanalysis of this laboratory.

Solvents were dried using the following methods: Dichloromethane was distilled from $\mathrm{P}_{2} \mathrm{O}_{5}$. Diethyl ether was distilled from $\mathrm{NaH}$. Hexane was distilled from $\mathrm{CaH}_{2}$. Tetrahydrofuran was distilled from lithium al uminum hydride just before use. All other solvents were of analytical grade. Thin layer chromatography (TLC) was carried out on Merck (Darmstadt, Germany) precoated silica gel 60 F 254 plates $(0.25 \mathrm{~mm})$ using the eluents indicated. Spots were visualized with UV or using a molybdate spray. "Flash" chromatography was carried out at a pressure of ca. 1.5 bar, using Merck Kieselgel $60 \mathrm{H}$. Col umn chromatography at atmospheric pressure was carried out using Merck Kiesel gel 60.

The synthesis of chlorolactones $\mathbf{1 1}$ and ent $\mathbf{1 1}$ was reported previously (Thuring et al., 1995).

Methyl 2-(1,3-Dioxo-1,3-dihydroi soindol-2-yl)-3-oxopropionate (9). To a cooled $\left(-10^{\circ} \mathrm{C}\right)$ solution of $8(65.8 \mathrm{~g}, 300 \mathrm{mmol})$ in methyl formate $(400 \mathrm{~mL})$ were gradually added small pieces of sodium $(6.90 \mathrm{~g}, 300 \mathrm{mmol})$, with mechanical stirring in a nitrogen atmosphere. Stirring was continued for $18 \mathrm{~h}$ until all sodium had dissolved. The reaction mixture was concentrated in vacuo, and to the residue was added a mixture of glacial acetic acid $(25 \mathrm{~mL})$ and $1 \mathrm{~N} \mathrm{HCl}(50 \mathrm{~mL})$. Crude 9 was obtained by extraction with dichloromethane (three times), drying $\left(\mathrm{MgSO}_{4}\right)$ and concentration in vacuo. Recrystallization from toluene gave pure $\mathbf{9}(59.3 \mathrm{~g}, 80 \%)$ as a pale yellow powder, with physical properties identical with those reported previously (Sheehan and J ohnson, 1954).

Methyl 2-(1,3-Dioxo-1,3-dihydroi soi ndol-2-yl)-3-[4-methyl-5oxo-2,5-dihydrofuran-2(R)-yl oxy]acrylate (rac 7). Potassium tert-butoxide ( $372 \mathrm{mg}, 3.32 \mathrm{mmol}$ ) was added to a cooled (0 ${ }^{\circ} \mathrm{C}$ ) and stirred solution of Sheehan aldehyde 9 (745 mg, 3.02 $\mathrm{mmol})$ in DMF $(10 \mathrm{~mL})$ at room temperature under nitrogen. Then chlorofuranone 10 (480 mg, $3.62 \mathrm{mmol})$ in DMF (3 mL) was gradually added. The mixture was stirred at room temperature over a weekend. DMF was removed in vacuo, and the residue was dissolved in a mixture of water and ethyl acetate. The organic layer was separated, and the aqueous phase was extracted with ethyl acetate (two times). The combined organic layers were washed with water (two times), dried $\left(\mathrm{MgSO}_{4}\right)$, and concentrated in vacuo. The oily residue was triturated with di isopropyl ether. Almost pure rac 7 (660 $\mathrm{mg}, 64 \%$ ) was isolated as a white solid by filtration and washing with diisopropyl ether. An analytical sample was obtained by recrystallization from 2-propanol. mp 151-152

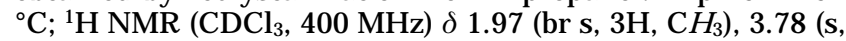
$\left.3 \mathrm{H}, \mathrm{OCH}_{3}\right), 6.17$ (br s, $\left.1 \mathrm{H}, \mathrm{OCHO}\right), 6.90(\mathrm{br} \mathrm{s}, 1 \mathrm{H},=\mathrm{CH}), 7.76$ $(\mathrm{m}, 2 \mathrm{H}, 2$ arom H ), $7.90(\mathrm{~m}, 3 \mathrm{H}, 2$ arom $\mathrm{H}+=\mathrm{CHO}) ; \mathrm{MS}$ [EI, $\mathrm{m} / \mathrm{z}$, rel intensity (\%)] $343\left([\mathrm{M}]^{+}, 2.7\right), 246\left(\left[\mathrm{C}_{12} \mathrm{H}_{8} \mathrm{NO}_{5}\right]^{+}, 100\right)$, $97\left(\left[\mathrm{C}_{5} \mathrm{H}_{5} \mathrm{O}_{2}\right]^{+}, 59.3\right)$. Anal. Calcd for $\mathrm{C}_{17} \mathrm{H}_{13} \mathrm{NO}_{7}$ : $\mathrm{C}, 59.48 ; \mathrm{H}$, 3.82; N, 4.08. Found: C, 59.10; $\mathrm{H}, 3.85 ; \mathrm{N}, 4.00$.

Methyl 2-(1,3-Dioxo-1,3-dihydroisoindol-2-yl)-3-[6(S)-methyl5-oxo-4-oxatricycl o[5.2.1.0 2,6]dec-8-en-3(R)-yl oxy]acrylate (12). Potassium tert-butoxide (149 mg, $1.33 \mathrm{mmol}$ ) was added to a stirred solution of Sheehan aldehyde $\mathbf{9}(302 \mathrm{mg}, 1.22 \mathrm{mmol})$ in DMF $(10 \mathrm{~mL})$ at room temperature under nitrogen. Then chlorolactone 11 (265 mg, $1.33 \mathrm{mmol})$ in DMF (3 mL) was gradually added. The mixture was stirred at $55^{\circ} \mathrm{C}$ for 7 days and then quenched with acetic acid $(0.5 \mathrm{~mL})$. DMF was removed in vacuo, and the residue was dissolved in a mixture of water and ethyl acetate. The organic layer was separated, and the aqueous phase was extracted with ethyl acetate (two times). The combined organic layers were washed with water (two times), dried $\left(\mathrm{MgSO}_{4}\right)$, and concentrated in vacuo. The crude product was purified by flash chromatography $\left(\mathrm{SiO}_{2}\right.$, hexane/ethyl acetate 2:1) to give 12 (143 mg, 29\%) as a yellowish solid. An analytical sample was obtained by recrystallization from dii sopropyl ether/ethyl acetate. mp 179.5-181 ${ }^{\circ} \mathrm{C} ;[\alpha]_{\mathrm{D}}-22^{\circ}\left(\mathrm{c} 0.2, \mathrm{CHCl}_{3}\right) ;{ }^{1} \mathrm{H} \mathrm{NMR}\left(\mathrm{CDCl}_{3}, 400 \mathrm{MHz}\right) \delta 1.46$ $\left(\mathrm{s}, 3 \mathrm{H}, \mathrm{CH}_{3}\right), 1.65\left(\mathrm{~m}, 2 \mathrm{H}, \mathrm{H}_{10}\right), 2.62(\mathrm{dd}, 1 \mathrm{H}, \mathrm{J}=4.2 \mathrm{~Hz}, \mathrm{~J}<$ $\left.1 \mathrm{~Hz}, \mathrm{H}_{2}\right), 2.85\left(\mathrm{~m}, 1 \mathrm{H}, \mathrm{H}_{7}\right), 3.16\left(\mathrm{~m}, 1 \mathrm{H}, \mathrm{H}_{1}\right), 3.77(\mathrm{~s}, 3 \mathrm{H}$, $\left.\mathrm{OCH}_{3}\right), 5.26\left(\mathrm{~d}, 1 \mathrm{H}, \mathrm{J}<1 \mathrm{~Hz}, \mathrm{H}_{3}\right), 6.17\left(\mathrm{~m}, 1 \mathrm{H}, \mathrm{H}_{9}\right), 6.28(\mathrm{~m}$, $\left.1 \mathrm{H}, \mathrm{H}_{8}\right), 7.77(\mathrm{~m}, 2 \mathrm{H}, \mathrm{Ar} \mathrm{H}), 7.85(\mathrm{~s}, 1 \mathrm{H},=\mathrm{CHO}), 7.91(\mathrm{~m}, 2 \mathrm{H}$, $\mathrm{Ar} \mathrm{H}) ; \mathrm{MS}\left[\mathrm{EI}, \mathrm{m} / \mathrm{z}\right.$, rel intensity (\%)] $409\left([\mathrm{M}]^{+}, 0.6\right), 344$ $\left(\left[\mathrm{C}_{17} \mathrm{H}_{14} \mathrm{NO}_{7}\right], 0.5\right), 247\left(\left[\mathrm{C}_{12} \mathrm{H}_{9} \mathrm{NO}_{5}\right], 43.6\right), 163\left(\left[\mathrm{C}_{10} \mathrm{H}_{11} \mathrm{O}_{2}\right]\right.$, 78.2), $97\left(\left[\mathrm{C}_{5} \mathrm{H}_{5} \mathrm{O}_{2}\right], 100\right), 66\left(\left[\mathrm{C}_{5} \mathrm{H}_{6}\right], 13.5\right)$. Anal. Calcd for $\mathrm{C}_{22} \mathrm{H}_{19} \mathrm{NO}_{7}$ : C, 64.54; $\mathrm{H}, 4.68 ; \mathrm{N}, 3.43$. Found: $\mathrm{C}, 64.52 ; \mathrm{H}$, 4.63; N, 3.48 .

Methyl 2-(1,3-Dioxo-1,3-dihydroisoi ndol-2-yl)-3-[6(R)-methyl5-oxo-4-oxatricycl o[5.2.1.02,6]dec-8-en-3(S)-yl oxy]acrylate (ent 12). This compound was prepared in the same way as described for 12, starting from Sheehan aldehyde $\mathbf{9}(601 \mathrm{mg}$, $2.43 \mathrm{mmol}$ ) and chlorolactone ent $\mathbf{1 1}(530 \mathrm{mg}, 2.67 \mathrm{mmol})$. Yield: $286 \mathrm{mg}, 29 \%$ of ent $\mathbf{1 2}$ as yellowish solid. Recrystallization from diisopropyl ether/ethyl acetate afforded analytically pure ent $12 . \mathrm{mp} 179.5-181^{\circ} \mathrm{C} ;[\alpha]_{\mathrm{D}}+23^{\circ}$ ( $\mathrm{c} 0.2, \mathrm{CHCl}_{3}$ ). Anal. Calcd for $\mathrm{C}_{22} \mathrm{H}_{19} \mathrm{NO}_{7}$ : C, 64.54; $\mathrm{H}, 4.68 ; \mathrm{N}, 3.43$. Found: C, 64.50; H, 4.64; N, 3.47. ${ }^{1} \mathrm{H}-\mathrm{NMR}$ and mass data were the same as for compound $\mathbf{1 2}$.

Methyl 2-(1,3-Dioxo-1,3-dihydroi soi ndol-2-yl)-3-[4-methyl-5oxo-2,5-dihydrofuran-2(R)-yl oxy]acrylate (7). Cycloadduct 12 (159 mg, $0.39 \mathrm{mmol}$ ) was dissolved in o-dichlorobenzene (40 $\mathrm{mL}$ ) and heated at $180^{\circ} \mathrm{C}$ for $7 \mathrm{~h}$. The solvent was removed in vacuo. The residue was purified by flash chromatography $\left(\mathrm{SiO}_{2}\right.$, hexane/ethyl acetate $\left.1: 1\right)$ to give 7 (53 mg, 40\%) as a colorless oil, which failed to crystallize. $[\alpha]_{\mathrm{D}}+124^{\circ}\left(\mathrm{c} 0.15, \mathrm{CH}_{2^{-}}\right.$ $\mathrm{Cl}_{2}$ ). ${ }^{1} \mathrm{H}-\mathrm{NMR}$ and mass data were the same as for compound rac 7. 


\section{Scheme 2. Preparation of rac 7}

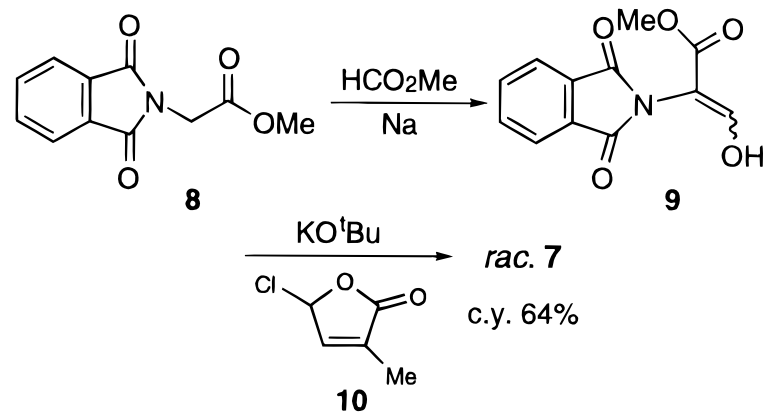

Methyl 2-(1,3-dioxo-1,3-dihydroi soindol-2-yl)-3-[4-methyl-5oxo-2,5-dihydrofuran-2(S)-yl oxy]acrylate (ent 7) was prepared in the same way as described for 7, starting from ent $\mathbf{1 2}$ (230 $\mathrm{mg}, 0.56 \mathrm{mmol}$ ). Yield: $43 \mathrm{mg}, 31 \%$ of ent $\mathbf{7}$ as a colorless oil, which failed to crystallize. $[\alpha]_{D}-128^{\circ}$ (c $0.15, \mathrm{CH}_{2} \mathrm{Cl}_{2}$ ). ${ }^{1} \mathrm{H}$ NMR and mass data were the same as for compound 7.

Biological Activity. Seeds. Seeds of Striga hermonthica (Del.) Benth [from Sorghum bicol or (L.) Mœench] and Orobanche crenata Forsk. (from Vicia faba L.) were harvested in Sudan in 1988 and in Egypt in 1991, respectively, and were stored in the dark at room temperature until use in germination tests.

Preparation of Test Solutions. A compound to be tested was weighed out very accurately to the amount of $10 \mathrm{mg}$, dissolved in $10 \mathrm{~mL}$ of acetone p.a., and diluted with demineralized water to $100 \mathrm{~mL}$. Aliquots of this stock sol ution were further diluted with water to obtain test solutions containing $2,1,0.1$, and $0.01 \mathrm{mg} / \mathrm{L}$ test compound and $0.2,0.1,0.01$, and $0.001 \%(\mathrm{v} / \mathrm{v})$ acetone, respectively.

Bioassays. F or surface sterilization seeds of S. hermonthica and $\mathrm{O}$. crenata were exposed to an aqueous sol ution of sodium hypochl orite ( $2 \%$ active chlorine) for $5 \mathrm{~min}$ with agitation. The seeds were then thoroughly rinsed with water and dried overnight.

For conditioning the sterilized seeds were spread on glass fiber filter paper disks (8-mm diameter; approximately 3070 seeds per disk) in Petri dishes, wetted with water, and stored in the dark for 14 days at $20^{\circ} \mathrm{C}$ for Orobanche seeds and at $30{ }^{\circ} \mathrm{C}$ for Striga seeds. Then the conditioning water was removed and replaced by $100 \mu \mathrm{L}$ of test solution per disk. After incubation for $24 \mathrm{~h}$ (Striga) and 5 days (Orobanche) in the dark at indicated temperatures, the germination percentage was determined under a microscope. Seeds were considered to be germinated if the radical protruded through the seed coat.

In each test series aqueous solutions with $0.1,0.01$, and $0.001 \%(\mathrm{v} / \mathrm{v})$ acetone were used as negative control. Test solutions of the stimulant GR24 (as a 1:1 diastereomeric mixture at concentrations of $1,0.1$, and $0.01 \mathrm{mg} / \mathrm{L}$ ) were used as positive controls. All tests were performed in duplicate, and in each test the germination percentages were determined on 12 disks per treatment.

For full details of the bioassay, see Mangnus et al. (1992c).

\section{RESULTS AND DISCUSSION}

The key step in the synthesis of rac $\mathbf{7}$ involves coupling of aldehyde 9 with 5-chloro-3-methyl-2(5H)furanone (10). This aldehyde $\mathbf{9}$ was prepared by condensation of methyl N-phthaloylglycinate (8) with methyl formate using metallic sodium (Scheme 2).

This procedure, which closely resembles that described by Schutz (1978), is superior to that originally reported by Sheehan and J ohnson (1954). It should be noted that $\mathbf{9}$ is a stable, crystalline compound, which can be stored for several years. The coupling reaction with butenolide $\mathbf{1 0}$ (Scheme 2) proceeded in high yield, and purification was readily accomplished by recrystallization. It is important to note that only one geometrical isomer was obtained. The correct geo-

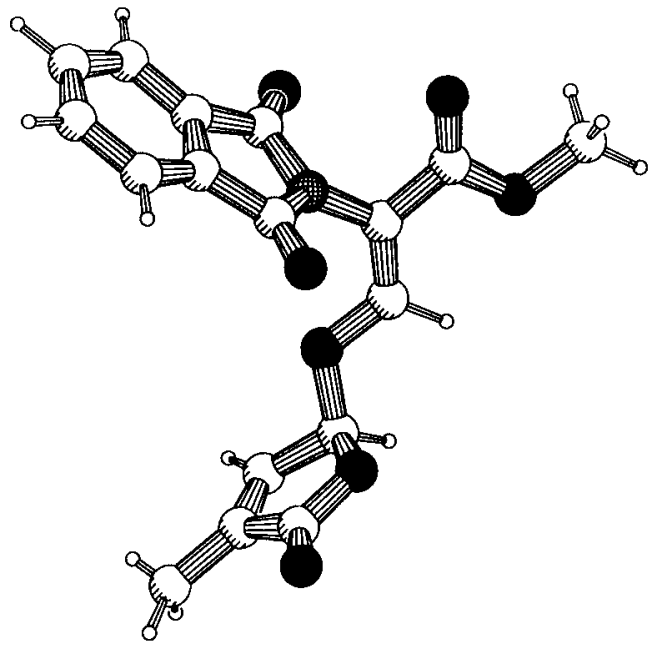

Figure 2. PLUTON-generated drawing of X-ray crystal structure of Nijmegen 1 (rac 7).

Table 1. Germination Percentages for Seeds of $\mathbf{S}$. hermonthica after Exposure to Aqueous Solutions of Strigol Analogues GR24 and Nijmegen 1 at Concentrations of 1 and $0.01 \mathrm{mg} / \mathrm{L}^{\mathrm{a}}$

\begin{tabular}{cllr} 
& & \multicolumn{2}{c}{$\%$ germination $\pm \mathrm{SE}$} \\
\cline { 3 - 4 } entry & \multicolumn{1}{c}{ stimulant } & \multicolumn{1}{c}{$1 \mathrm{mg} / \mathrm{L}$} & $0.01 \mathrm{mg} / \mathrm{L}$ \\
\hline 1 & GR24 (5) & $45.5 \pm 13.5$ & $52.5 \pm 12.5$ \\
2 & Nijmegen 1 (rac 7) & $40.3 \pm 1.7$ & $4.1 \pm 0.9^{\mathrm{b}}$
\end{tabular}

a Activities are indicated as germination percentages after treatment of the seeds with test solutions at $1 \mathrm{mg} / \mathrm{L}$ and $0.01 \mathrm{mg} /$ $\mathrm{L}$. Germination percentages given are the mean $\pm \mathrm{SE}$ of two replicate tests. ${ }^{b}$ Value is not significantly different from germination percentages obtained in the control (without stimulant)

metrical structure could not be deduced unambiguously by spectroscopi c means, and therefore an X-ray diffraction analysis was undertaken (Beurskens et al., 1994). The structure of $\mathbf{7}$ is depicted in Figure 2, showing that the Z-isomer was obtained.

Next, the preparation of the individual enantiomers of 7 was attempted, using enantiomerically pure tricyclic chlorolactones $\mathbf{1 1}$ and ent $\mathbf{1 1}$ as the D-ring precursors (Scheme 3). The stereosel ective synthesis of $\mathbf{1 1}$ and ent $\mathbf{1 1}$ and their use in the preparation of the single isomers of strigol analogues has been reported recently (Thuring et al., 1995).

The coupling reactions of Sheehan aldehyde $\mathbf{9}$ with $\mathbf{1 1}$ and ent $\mathbf{1 1}$ did not proceed as smoothly as was observed for the corresponding GR 7 anal ogues (Thuring et al., 1995). As a result of the relatively poor nucleophilicity of the enolate anion derived from 9, a higher reaction temperature was required, which caused concomitant decomposition of $\mathbf{1 1}$ and ent $\mathbf{1 1}$. The cycloreversion of $\mathbf{1 2}$ and ent $\mathbf{1 2}$ was performed in o-dichlorobenzene at $180{ }^{\circ} \mathrm{C}$ to give 7 and ent 7, respectively, in moderate yields. The ee values of both enantiomers were $>98 \%$, as was determined by ${ }^{1} \mathrm{H}-\mathrm{NMR}$ analysis using the chiral shift reagent $\mathrm{Eu}(\mathrm{hfC})_{3}$.

Biological Evaluation. The germination stimulatory activity of Nijmegen 1 (rac 7) was assayed using seeds of $\mathrm{S}$. hermonthica and $\mathrm{O}$. crenata spp. In each bi oassay, GR24 was included as a positive control. The procedure enables a comparison between results obtained in different test series. This is important, since the response of seeds of parasitic weeds, especially $\mathrm{S}$. hermonthica, varies considerably from test to test. In addition, the activities of enantiomers $\mathbf{7}$ and ent $\mathbf{7}$ were determined using seeds of $\mathrm{O}$. crenata spp. The results 
Scheme 3. Enantioselective Syntheses of 7 and ent 7<smiles>COC(=O)/C(=C/O[C@H]1C=C(C)C(=O)O1)C(=O)N1C(=O)c2ccccc2C1=O</smiles>

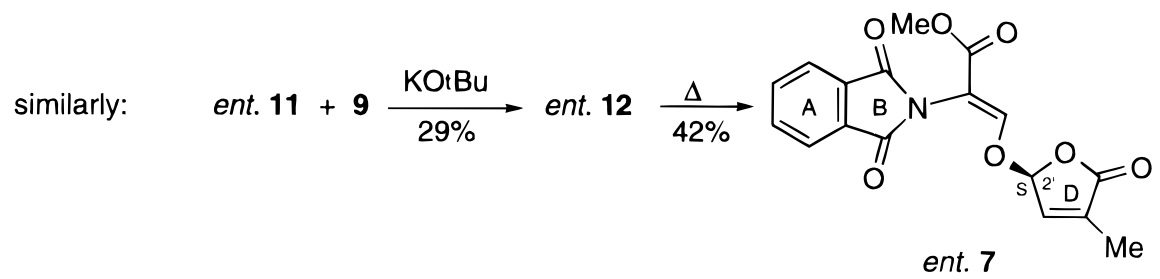

Table 2. Germination Percentages for Seeds of O. crenata after Exposure to Aqueous Solutions of Strigol Analogues GR24 and Nijmegen 1 at Concentrations of $2,1,0.1$, and $0.01 \mathrm{mg} / \mathrm{L}^{\mathrm{a}}$

\begin{tabular}{clcccc}
\hline & & \multicolumn{3}{c}{$\%$ germination $\pm \mathrm{SE}$} \\
\cline { 3 - 5 } entry & compound & $2 \mathrm{mg} / \mathrm{L}$ & $1 \mathrm{mg} / \mathrm{L}$ & $0.1 \mathrm{mg} / \mathrm{L}$ & $0.01 \mathrm{mg} / \mathrm{L}$ \\
\hline 1 & GR24 (5) & $58.3 \pm 1.3$ & $62.5 \pm 3.6$ & $36.0 \pm 10.6$ & $3.4 \pm 1.1$ \\
2 & Nijmegen 1 (rac 7) & $42.6 \pm 1.8$ & $5.6 \pm 0.6$ & $1.1 \pm 0.6^{\mathrm{b}}$ \\
3 & Nijmegen 1 (7) & & $54.8 \pm 3.4$ & $34.5 \pm 2.2$ & \\
4 & Nijmegen 1 (ent 7) & & $26.9 \pm 0.3$ & $6.5 \pm 1.3$
\end{tabular}

\footnotetext{
a Germination percentages given are the mean \pm SE of two replicate tests. ${ }^{b}$ Value is not significantly different from germination
} percentages obtained in the control (without stimulant).

are collected in Tables 1 and 2. It was beyond the aim of this study to establish complete dose-response curves, implying that the data obtained allow only an interpretation in a qualitative sense.

The data in Table 1 (S. hermonthica spp.) reveal that rac Nijmegen 1 exhibits considerable activity at the higher concentration of $1 \mathrm{ppm}$, whereas it is practically inactive at a concentration of $0.01 \mathrm{ppm}$. Similarly, in thestimulation of $O$. crenata spp. seeds, $\operatorname{rac} 7$ has shown a bioactivity comparable to that of GR24 at higher concentrations (entry 1, Table 2). Comparison of the germination percentages exerted by enantiopure 7 and ent 7 (entries 2 and 3, Table 2 ) reveals that the former is consi derably more active. Thus, the absolute stereochemistry at C- 2 ' in the D-ring should be the Rconfiguration to germinate a maximum number of seeds. This configuration is the same as in natural (+)-strigol . This result is in agreement with previous conclusions from comparative studies of the bi oactivity of all stereoisomers of GR7 (Mangnus and Zwanenburg, 1992b) and of some stereoisomers of strigol (Bergmann et al., 1993), namely, that the most active stereoisomer has the $\mathrm{R}$-configuration at $\mathrm{C}-2^{\prime}$ in the D-ring.

From the results presented above, it may be concluded that phthal oylglycine-derived strigol analogue rac $\mathbf{7}$ is a potent germination stimulant of seeds of $\mathrm{S}$. hermonthica and $\mathrm{O}$. crenata spp. Moreover, optically active 7 with the "natural" configuration in the D-ring has a stimulatory activity comparable to that of GR24 for O. crenata. The charm of this particular stimulant is the fact that its racemic preparation is very simple and that it can be carried out without any chromatographic separation, which makes it an attractive compound for large-scale preparations and accordingly for use in the suicidal approach in the weed pest control. Moreover, the achiral "ABC"-part in rac $\mathbf{7}$ enables a rapid evalu- ation of the structural variation in the D-ring on the stimulatory activity. Research in this direction is in progress.

It should be noted that our newly developed asymmetric route all ows for the first time the synthesis of a strigol analogue, which is only chiral at the D-ring. The ease of preparation and the high bioactivity of this new germination stimulant warrant further studies to evaluate its activity and stability under soil conditions. Activities in this direction are in progress.

From a mechanistic point of view we can conclude that a possible interaction of the ABC-fragment with a receptor site is sterically and el ectronically not highly demanding.

\section{ACKNOWLEDGMENT}

We thank Dr. A. G. T. Babiker and Dr. F. M. F. Zaitoun for supplying Striga and Orobancheseeds. We also thank H. Amatdjais, P. van Galen, and A. Swolfs for conducting elemental analysis, mass, and $400 \mathrm{MHz}$ ${ }^{1} \mathrm{H}-\mathrm{NMR}$ measurements.

\section{LITERATURE CITED}

Bergmann, C.; Wegmann, K.; Frischmuth, K.; Samson, E.; Kranz, A.; Weigelt, D.; Koll, P.; Welzel, P. Stimulation of Orobanche crenata seed germination by $(+)$-strigol and structural analogues. Dependence of constitution and configuration of the germination stimulants. J. Plant Physiol. 1993, 142, 338-342 and references cited therein.

Beurskens, G.; Smits, J . M. M.; Beurskens, P. T.; Beenakkers, M.; Nefkens, G.; Zwanenburg, B. Crystal and molecular structure of 2-(1,3-dioxo-1,3-dihydro-isoindol-2-yl)-3-(4methyl-5-oxo-2,5-dihydro-furan-2-yloxy)acrylic acid methyl ester, $\mathrm{C}_{17} \mathrm{H}_{13} \mathrm{NO}_{7}$. J . Chem. Crystallogr. 1994, 24, 643-646.

Butler, L. G. Chemical communication between the parasitic weed Striga and its crop host. ACS Symp. Ser. 1995, No. 582, 158-166. 
Cook, C. E.; Whichard, L. P.; Turner, B.; Wall, M. E.; Egley, G. H. Germination of witchweed (S. Iutea Lour.): isolation and properties of a potent stimulant. Science 1966, 11891190.

Cook, C. E.; Whichard, L. P.; Wall, M. E.; Egley, G. H.; Coggan, P.; Luhan, P. A.; M CPhail, A. T. Germination stimulants II. The structure of strigol-a potent seed germination stimulant for witchweed (Striga lutea Lour.). J . Am. Chem. Soc. 1972, 94, 6198-6199.

Eplee, R. E. Ethylene: a witchweed seed germination stimulant. Weed Sci. 1975, 23, 433-436.

Hassanali, A. Strigol analogues: synthetic achievements and prospects. In Striga; Biology and Control; Ayensu, E. S., Doggett, H., Keynes, K. D., Marton-Lefevre, J ., Mussel man, L. J ., Parker, C., Peckering, A., Eds.; ICSU Press; Paris, 1984; pp 125-132.

Hauck, C., Müller, S., Schildknecht, H. A germination stimulant for parasitic flowering plants from Sorghum bicolor, a genuine host plant. J . Plant Physiol. 1992, 139, 474-478.

J ohnson, A. W.; Roseberry, G.; Parker, C. A novel approach to Striga and Orobanche control using synthetic germination stimulants. Weed Res. 1976, 16, 223-227.

J ohnson, A. W.; Gowda, G.; Hassanali, A.; Knox, J .; Monaco, S.; Razawi, Z.; Roseberry, G. The preparation of synthetic analogues of strigol. J . Chem. Soc., Perkin Trans. 1 1981, 1734-1743.

Mangnus E. M.; Zwanenburg, B. Tentative molecular mechanism for germination stimulation of Striga and Orobanche seeds by strigol and its synthetic analogues. J . Agric. F ood Chem. 1992a, 40, 1066-1070.

Mangnus E. M.; Zwanenburg, B. Synthesis, structural characterization, and biological evaluation of all four enantiomers of strigol analogue GR 7. J . Agric. Food Chem. 1992b, 40, 697-700.

Mangnus E. M.; van Vliet, L. A.; Vandenput, D. A. L.; Zwanenburg, B. Structural modifications of strigol analogues. Influence of the $B$ and $C$ rings on the bioactivity of the germination stimulant GR24. J. Agric. Food Chem. 1992a, 40, 1222-1229.

Mangnus E. M.; Dommerholt, F. J ; de J ong, R. L. P.; Zwanenburg, B. Improved synthesis of strigol analogue GR24 and evaluation of the biological activity of its diastereomers. J . Agric. Food Chem. 1992b, 40, 1230-1235.

Mangnus, E. M.; Stommen, P. L. A.; Zwanenburg, B. A standardized bioassay for evaluation of potential germination stimulants for seeds of parasitic weeds. J . Plant Growth Regul. 1992c, 11, 91-98.

Müller, S.; Hauck, C.; Schildknecht, H. Germination stimulants produced by Vigna unguiculata Walp cv Saunders Upright. J . Plant Growth Regul. 1992, 11, 77-84.
Musselman, L. J ., Ed. Parasitic Weeds in Agriculture Vol. I. Striga; CRC Press: Boca Raton, FL, 1987; 317 pp.

Parker, C.; Riches, C. R. Parasitic Weeds of the World: Biology and Control; CAB International Press: Wallingford, Oxon, U.K., 1993; 332 pp.

Press, M. C.; Graves, J . D.; Stewart, G. R. Physiology of the interaction of angiosperm parasites and their higher plant hosts. Plant, Cell Environ. 1990, 13, 91-104

Schutz, A. Totalsynthese von Penicillin-und Cephalosporinderivate mittels Vierkomponenten-kondensation und Mechanistische Studien. Doctoral Thesis, T.U. München, 1978.

Sheehan, J . C.; J ohnson, D. A. The synthesis of substituted penicillins and simpler structural analogs. VIII. Phthalimidomal onaldehydic esters: Synthesis and condensation with penicillamine. J . Am. Chem. Soc. 1954, 76, 158-160.

Siame, B. A.; Weerasuriya, Y.; Wood, K.; Ejeta, G.; Butler, L. G. I solation of strigol, a germination stimulant for Striga asiatica, from host plants. J . Agric. Food Chem. 1993, 41, 1486-1491.

Thuring, J. W. J . F.; Nefkens, G. H. L.; Schaafstra, R.; Zwanenburg, B. Asymmetric synthesis of a D-ring synthon for strigol analogues and its application to the synthesis of all four stereoi somers of germination stimulant GR7. Tetrahedron 1995, 51, 5047-5056.

Vail, S. L.; Dailey, O. D.; Blanchard, E.J .; Pepperman, A. B.; Riopel, J . L. Terpenoid precursors of strigol as seed germination stimulants of broomrape (Orobanche ramosa) and witchweed (Striga asiatica). J . Plant Growth Regul. 1990, 9, 77-83 and references cited therein.

Zwanenburg, B.; Mangnus, E. M.; Thuring, J . W. J . F. Strigol analogues: design, synthesis and biological activity. In Proceedings of the Third International Workshop on Orobanche and Related Striga Research; Pieterse, A. H. Verkley, J. A. C., Ter Borg, S. J., Eds.; Royal Tropical Institute: Amsterdam, The Netherlands, 1994; pp 187-197.

Received for review J une 24, 1996. Revised manuscript received J anuary 2, 1997. Accepted J anuary $9,1997 .{ }^{\otimes}$ These investigations were supported by the Netherlands Foundation of Chemical Research (SON) with financial aid from the Netherlands Organization for the Advancement of Research (NWO).

\section{J F9604504}

${ }^{\otimes}$ Abstract published in AdvanceACS Abstracts, April 1, 1997. 